\title{
Thrips species (Thysanoptera, Terebrantia) inhabiting irrigated rice and surrounding habitats in Cachoeirinha, state of Rio Grande do Sul, Brazil
}

\author{
Adriano Cavalleri ${ }^{1}$, Milton de Souza Mendonça $\mathrm{Jr}^{1}{ }^{\text {\& Everton Nei Lopes Rodrigues }}{ }^{1,2}$
}

${ }^{1}$ Laboratório de Ecologia de Interações, Departamento de Ecologia, Instituto de Biologia, Universidade Federal do Rio Grande do Sul, Av. Bento Gonçalves, 9500, 91501-970 Porto Alegre-RS, Brazil. cavalleri_adriano@yahoo.com.br; milton.mendonca@ufrgs.br

${ }^{2}$ Museu de Ciências Naturais, Fundação Zoobotânica do Rio Grande do Sul, Rua Dr. Salvador França, 1427, 90690-000 Porto Alegre-RS, Brazil. enlrodrigues@yahoo.com.br

\begin{abstract}
Thrips species (Thysanoptera, Terebrantia) inhabiting irrigated rice and surrounding habitats in Cachoeirinha, state of Rio Grande do Sul, Brazil. In Brazil, almost nothing is known about the thrips fauna associated with rice crops. This is especially true for Rio Grande do Sul State (RS), the major rice producer in Brazil, where no systematic surveys have been conducted. Thus, this work records preliminarily the species of suborder Terebrantia inhabitanting irrigated rice (RC) and three nearby habitats: the area selected for rice, before cultivation (BR), grassland (GR) and forest border (FB) in Cachoeirinha, RS (50 $58^{\prime} 21^{\prime \prime} \mathrm{W}$; $29^{\circ} 55^{\prime} 30^{\prime \prime}$ S). Eight field trips were carried out between October/2004 and February/2005 to Estação Experimental do Arroz in Cachoeirinha. Thrips specimens were collected with sweeping net and transported to laboratory for identification. A total of 623 adults terebrantians were recorded, belonging to two families and 18 species. Frankliniella rodeos (55.5\%), Neohydatothrips cf. paraensis (30.3\%) and Frankliniella schultzei (5.6\%), were the most abundant, comprising more than $90 \%$ of the individuals. FB showed the highest species richness $(\mathrm{S}=15)$, followed by $\mathrm{GR}(\mathrm{S}=10), \mathrm{RC}(\mathrm{S}=9)$ and $\mathrm{BR}(\mathrm{S}=6)$. FB presented a low number of individuals (14.0\%), contrasting with GR (44.8\%) and BR (36.7\%). In general, thrips abundance in RC was low at EEA (4.5\%), and few species seems to effectively use rice as a host-plant. Two species previously considered of economic importance were found, F. rodeos and F. schultzei, the latter a new record for rice in Brazil. Five species are new records to RS.
\end{abstract}

KEYWORDS. Entomology; Frankliniella; inventories; Oryza sativa; phytophagous insects.

RESUMO. Espécies de tripes (Thysanoptera, Terebrantia) habitantes do arroz irrigado e habitats adjacentes em Cachoeirinha, Rio Grande do Sul, Brasil. No Brasil, pouco se sabe a respeito da fauna de tripes associada à cultura do arroz. Isto é especialmente válido para o Rio Grande do Sul (RS), o maior produtor de arroz do país, onde nenhum levantamento sistemático tem sido realizado. Visando suprir tal lacuna, este estudo registra preliminarmente as espécies da subordem Terebrantia habitantes do arroz irrigado (RC) e de três habitats vizinhos: área antes do plantio do arroz (BR), campo (GR) e borda de mata (FB) em Cachoeirinha, RS (50 58'21'W; 29 55'30'S). Foram realizadas oito saídas de campo entre outubro de 2004 e fevereiro de 2005 para a Estação Experimental do Arroz em Cachoeirinha. Os tripes foram coletados através de varredura e levados até o laboratório para identificação. Foram amostrados 623 Terebrantia adultos, pertencendo a duas famílias e 18 espécies. Frankliniella rodeos (55,5\%), Neohydatothrips cf. paraensis (30,3\%) e Frankliniella schultzei (5,6\%), foram as espécies mais abundantes, perfazendo mais de $90 \%$ da amostra. FB apresentou a maior riqueza de espécies $(S=15)$, seguida por $\mathrm{GR}(\mathrm{S}=10), \mathrm{RC}(\mathrm{S}=9)$ e $\mathrm{BR}(\mathrm{S}=6)$. FB apresentou um baixo número de indivíduos $(14,0 \%)$, contrastando com GR $(44,8 \%)$ e BR $(36,7 \%)$. No geral, a abundância de tripes em RC na área de estudo foi baixa $(4,5 \%)$, e provavelmente poucas espécies usam efetivamente o arroz como hospedeira. Foram coletadas duas espécies de importância econômica, F. rodeos and F. schultzei, sendo esta última um novo registro para o arroz no Brasil. Cinco espécies são novos registros para o RS.

PALAVRAS-CHAVE. Entomologia; Frankliniella; insetos fitófagos; inventários; Oryza sativa.

The members of the Order Thysanoptera, commonly named thrips, are tiny insects comprising about 5,800 species. About $1 \%$ of these have economic importance in several cultivated plants, almost all of them belonging to the suborder Terebrantia (Mound \& Marullo 1996; Mound 2007). The damage produced by these insects is caused by direct injury to plant tissues (with their picking and sucking mouthparts) and also by indirect damage, through pathogen transmission (Mound \& Kibby 1998).

However, in some agricultural systems little is known about the thrips fauna associated and their possible effects on the crops. This is especially true for rice, where some thrips species are considered pests, causing productivity losses. The most important is the Oriental rice thrips, Stenchaetothrips biformis (Bagnall, 1913), a worldwide species that damages leaves and induces curling and drying of the tips. In Paleartic and Oriental regions, Haplothrips aculeatus (Fabricius, 1803) and Haplothrips ganglebaueri Schmutz, 1913, are also considered pests of rice, feeding on grain heads, causing a distorted development of the embryos (Grist \& Lever 1969; Chander 1999).

Although Brazil is a large rice producer and consumer (Embrapa Arroz e Feijão 2008), almost nothing has been published on the associated thrips species in this crop. An exception is the work of Ferreira \& Fernandes (1985), which recorded Frankliniella rodeos Moulton, 1933 damaging rice flowers in Goiás State, increasing the number of sterile spikelets. The lack of information is critical for Rio Grande do Sul State (RS), the main rice producer in Brazil (Embrapa Arroz e Feijão 2008), where no systematic inventories have been conducted so far. Particularly, the rice crops cultivated under irrigated conditions urgently need studies on surveys 
and characterization of potential insect pests and their natural enemies, aiming to obtain a correct identification of species and establish appropriated control methods (Costa 2007).

Thus, this work preliminarily records the thrips species of suborder Terebrantia inhabiting irrigated rice and three nearby habitats: preceding area where rice is cultivated, grassland and forest border in Cachoeirinha (RS).

\section{MATERIAL AND METHODS}

Study site. Field trips were carried out to Estação Experimental do Arroz (EEA) in Cachoeirinha, RS (50 $\left.58^{\circ} 21^{\prime \prime} \mathrm{W} ; 29^{\circ} 55^{\prime} 30^{\prime \prime} \mathrm{S}\right)$. The climate is humid subtropical (Cfa according to Köppen) and the temperature along the sample period ranged from $15^{\circ} \mathrm{C}$ to $29^{\circ} \mathrm{C}$. In EEA, the rice crop is delimited by riparian forest and grassland, and several herbaceous plants are associated with it: Aeschynomene denticulata Rudd (Fabaceae), Brachiaria plantaginea (Link) Hitchc. (Poaceae), Cyperus difformis L. (Cyperaceae), Echinochloa colonum (L.) Link (Poaceae), Heteranthera reniformis Ruiz \& Pavon (Pontederidaceae), Hymenachne amplexicaulis (Rudge) Nees (Poaceae), Panicum dichotomiflorum Michx (Poaceae), Thalia geniculata L. (Maranthaceae) (IRGA 2001).

Rice cropping. Oryza sativa L. (Poaceae) is originated from Asia and is widely cultivated in tropical and temperate climate countries. There are thousands of varieties of rice, which enable the plant to be grown successfully in different regions. It is cultivated in two main systems: the "upland" or "dry" one and the "irrigated" or "wet" one (Grist \& Lever 1969). In this study, the rice (variety BR IRGA 410) grown under irrigated conditions and was sowed in the middle of December/2004.

Sampling and analysis. Between October/2004 and February/2005 eight field trips were conducted to EEA. Thrips were collected by sweeping in four different habitats: (i) the area selected for rice, before cultivation (BR); (ii) the same area after rice sowing (RC); (iii) riparian forest border (FB) (80 $\mathrm{m}$ far from RC) and (iv) grassland (GR) (10 m away from RC). FB and GR were sampled eight times, while BR and $\mathrm{RC}$ were sampled three and five times, respectively. The thrips were kept in $60 \%$ ethanol and transported to the laboratory for identification using microscopy magnification. Slide preparation is the same as in Mound \& Kibby (1998) and nomenclature follows Mound (2007). The specimens are deposited in the zoological collection of Laboratório de Ecologia de Insetos, Departamento de Zoologia, UFRGS, Porto Alegre (Brazil). An individual-based rarefaction test was calculated using PASt software (Hammer et al. 2001).

\section{RESULTS}

A total of 623 adult terebrantians were recorded (440 females, $70.6 \%$ and 183 males, $29.4 \%$ ), belonging to two families and 18 species (Table I). F. rodeos $(\mathrm{N}=346,55.5 \%)$, Neohydatothrips cf. paraensis (Hood, 1954) ( $\mathrm{N}=189,30.3 \%)$ and Frankliniella schultzei (Trybom, 1910) $(\mathrm{N}=35,5.6 \%)$, were the most abundant species, comprising more than $90 \%$ of the number of individuals. In addition, these three species were the only ones present in all four habitats analyzed. $F$. rodeos was the dominant species for all habitats, including $\mathrm{RC}$, even at a low number $(\mathrm{N}=12,1.9 \%)$. Although abundant in the majority of habitats, $N$. cf. paraensis, was almost absent in $\mathrm{RC}(\mathrm{N}=1,0.2 \%)$.

With the exception of Stomatothrips rotundus Hood, 1949 $(\mathrm{N}=1,0.2 \%)$, known to exhibit a predatory habit, all other Terebrantia collected are phytophagous. Larvae and pupae were also recorded in all habitats, and the majority probably belongs to genus Frankliniella.

The number of females comprised about $70 \%$ of the total abundance. In three species, all singletons or doubletons, the males were not recorded. No females of Arorathrips fulvus (Moulton, 1936) and S. rotundus were recorded; however, these were singleton species.

FB showed the highest species richness $(\mathrm{S}=15)$, followed by $\mathrm{GR}(\mathrm{S}=10), \mathrm{RC}(\mathrm{S}=9)$ and $\mathrm{BR}(\mathrm{S}=6)$. However, using an individual rarefaction test, species richness in $\mathrm{RC}$ was shown to be significantly higher than all the other habitats (Fig. 1). In FB the number of species was also significantly higher than BR and GR. RC $(\mathrm{N}=28)$ and $\mathrm{FB}(\mathrm{N}=87)$ actually had a low number of individuals, indicating a high diversity, contrasting with $\mathrm{BR}(\mathrm{N}=229)$ and $\mathrm{GR}(\mathrm{N}=279)$, in which dominance by a few successful species is clear. Five species were habitatexclusive, but these were also singletons (Table I). Their number along with doubletons comprised about $45 \%$ of the recorded species.

\section{DISCUSSION}

Because of the lack of standardised thrips surveys on rice in Brazil, the species richness recorded in $\mathrm{RC}(\mathrm{S}=9)$ can not be contrasted with those from other regions of the country. The use of different collecting techniques and sampling effort probably strongly influences the number of species collected, hampering comparisons unless a standard method of survey is agreed upon. In the Philippines, using dissection of plant parts and yellow pan traps, Reves \& Rillon (1994) recorded 18 phytophagous terebrantians in irrigated rice. However, this difference in number of species is probably partially derived from the different climates of the two study areas. In tropical areas, species richness is higher, although the number of mycophagous thrips also increases in wet and warm countries (Marullo 1997; Mound 2002).

In general, thrips abundance in $\mathrm{RC}$ was low at EEA, and certainly few species effectively use the rice as a host plant. Although the species richness between $B R(S=6)$ and $R C$ $(\mathrm{S}=9)$ were not remarkably different, the number of individuals recorded was more than eight times higher in the first habitat (Table I). The high species richness estimated in RC (Fig. 1) is only a reflection of the low number of thrips in proportion of number of species observed. Nevertheless, at this moment there is no way to know if these species are occasional or they are all using the rice as feeding and reproductive site. 


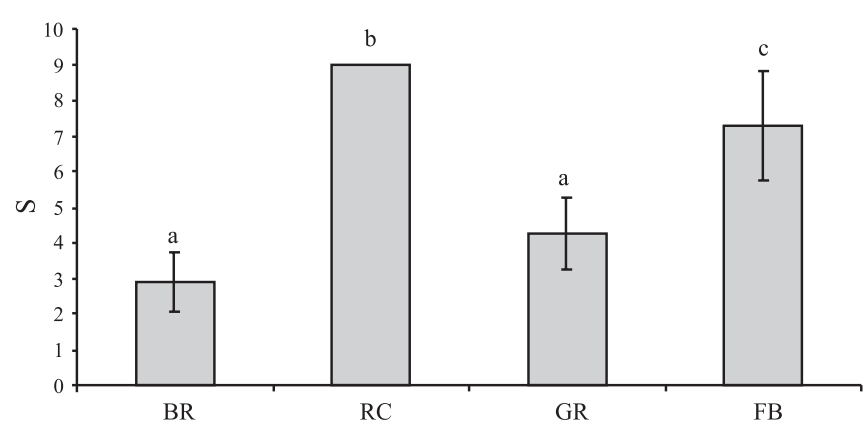

Fig.1. Species richness (S) of thrips (Terebrantia) in different habitats in EEA (Cachoeirinha, RS, Brazil) using an individual-based rarefaction test. BR: Before rice; RC: Rice; GR: Grassland; FB: Forest border. Different letters express significant differences in richness; error bars are $95 \%$ confidence intervals.

FB seems to support a high number of thrips species. This could be explained by higher vegetation diversity in FB, contrasting with the homogeneity of the others habitats. However, thrips abundance in this habitat is low, including the dominant species. For example, only $14 \%$ and $2 \%$ of individuals of $F$. rodeos and $F$. schultzei were collected in FB, respectively. In addition, more than $65 \%$ of the species recorded in FB was comprised by singletons. Thus, this habitat apparently does not constitute a source for thrips to other habitats and the maintenance of vegetation of FB near rice crops in EEA seems to offer little or no effects on presence of pest thrips.

GR showed the highest number of thrips but the species richness is similar to RC (Table I). This result is derived from the high abundance of $F$. rodeos in GR $(\mathrm{N}=157)$, which probably uses the numerous plant species of the herbaceous vegetation as host in this area. Analyzing those species with five or more individuals, all of them were collected in three or all four habitats. This can possibly indicate a high vagility by the thrips species recorded.

The absence of males in some species probably reflects the low abundance recorded on these. However, the number of females was higher than males in $77.7 \%$ species recorded. In addition, some of them showed a high relative frequency of females (e.g. F. schultzei, Arorathrips mexicanus (Crawford, 1909) and Bregmatothrips venustus Hood, 1912. According to Lewis (1973), female-biased sex-ratio populations in Thysanoptera are common in several thrips species. In some of them, the males are rare or remain unknown, suggesting parthenogenetic reproduction, sometimes induced by Wolbachia (Arakaki et al. 2001; Kumm \& Moritz 2008). Besides this, sex ratio in thrips also varies according to temperature, colonization patterns and geographical region (Lewis 1973).

The high abundance of $F$. rodeos in this study is not surprising. Cavalleri et al. (2006) also registered a large number of individuals of this species in several wild plants in a Conservation Unit placed about $45 \mathrm{~km}$ of EEA. Based on the studies of Pinent et al. (2006) and Cavalleri et al. (2006), together with personal observations, the genus Frankliniella certainly is the richest and most abundant group amongst Terebrantia in the state of Rio Grande do Sul.

It is also worth mentioning the high number of Arorathrips species recorded here $(S=4)$, representing $80 \%$ of the species referred for Brazil. This genus comprises flower grass feeding species that are common in cultivated pastures (Mound \& Kibby 1998). In addition, Mound \& Palmer (1972) states

Table I. Terebrantian species (Insecta: Thysanoptera) collected in four different habitats at Estação Experimental do Arroz in Cachoeirinha, State of Rio Grande do Sul, between October/2004 and February/2005. BR: Before rice; RC: Rice; GR: Grassland; FB: Forest border.

\begin{tabular}{|c|c|c|c|c|c|c|}
\hline Thrips species & $\mathrm{BR}(\mathrm{S}=6)$ & $\mathrm{RC}(\mathrm{S}=9)$ & GR $(S=10)$ & FB $(S=15)$ & Total & Sex ratio $(\mathrm{F}: \mathrm{M})$ \\
\hline \multicolumn{7}{|l|}{ Family Thripidae } \\
\hline Frankliniella rodeos Moulton & 129 & 12 & 157 & 48 & 346 & $1.52: 1$ \\
\hline Neohydatothrips cf. paraensis (Hood) & 92 & 1 & 81 & 15 & 189 & $4.72: 1$ \\
\hline Frankliniella schultzei (Trybom) & 2 & 5 & 27 & 1 & 35 & $10.7: 1$ \\
\hline Leucothrips sp. & 0 & 3 & 4 & 10 & 17 & $3.25: 1$ \\
\hline Arorathrips mexicanus (Crawford)* & 0 & 1 & 2 & 2 & 5 & $5: 0$ \\
\hline Bregmatothrips venustus Hood & 0 & 1 & 2 & 2 & 5 & $5: 0$ \\
\hline Frankliniella serrata Moulton & 3 & 0 & 0 & 1 & 4 & $4: 0$ \\
\hline Arorathrips fulvus (Moulton) & 0 & 3 & 1 & 0 & 5 & $3: 1$ \\
\hline Thrips australis (Bagnall) & 0 & 0 & 3 & 1 & 4 & $4: 0$ \\
\hline Arorathrips xanthius (Hood)* & 2 & 0 & 0 & 1 & 3 & $1: 2$ \\
\hline Arorathrips nigriceps (Hood)* & 1 & 0 & 0 & 1 & 2 & $2: 0$ \\
\hline Frankliniella trinidadensis Hood & 0 & 1 & 0 & 1 & 2 & $2: 0$ \\
\hline Plesiothrips sp. & 0 & 0 & 1 & 1 & 2 & $0: 2$ \\
\hline Caliothrips phaseoli (Hood) & 0 & 0 & 0 & 1 & 1 & $1: 0$ \\
\hline Chirothrips texanus Andre* & 0 & 0 & 1 & 0 & 1 & $1: 0$ \\
\hline Chirothrips sp. & 0 & 0 & 0 & 1 & 1 & $1: 0$ \\
\hline Frankliniella gemina Bagnall & 0 & 1 & 0 & 0 & 1 & $1: 0$ \\
\hline \multicolumn{7}{|l|}{ Family Aeolothripidae } \\
\hline Stomatothrips rotundus Moulton* & 0 & 0 & 0 & 1 & 1 & $0: 1$ \\
\hline Total & 229 & 28 & 279 & 87 & 623 & - \\
\hline
\end{tabular}

* New records for the State of Rio Grande do Sul 
that these thrips may be important in limiting production of grasses when they are grown for seed.

Of the thrips collected in RC, two of them are previously considered of economic importance, F. rodeos and F. schultzei, the latter a new record for rice in Brazil. As mentioned above, Ferreira \& Fernandes (1985) recorded $F$. rodeos in rice flowers in Goiás State, causing damage to the spikelets. F. schultzei is a native polyphagous thrips that attacks several plants species around the world and is considered a major pest amongst Thysanoptera (Monteiro et al. 1999). Although both species had low abundance in RC, a monitoring of these populations is suggested, given their potential as pests. One of the few species recorded to Rio Grande do Sul State on rice (Costa Lima 1936), S. biformis, was not recorded in this study. This record could be a misidentification and unfortunately there is no indication where this material is deposited. If present, this thrips, characteristic of Tropical regions, is certainly not abundant in EEA.

A compilation of the scarce preexisting published data about Brazilian thrips fauna on rice (Silva et al. 1968; Rosseto et al. 1972; R. C. Monteiro, pers. comm.) indicated that only six terebrantian species were previously recorded for this crop. Of these, only F. rodeos was recorded in the present study. Consequently, 17 Terebrantia species are now referred for rice in Brazil. In addition, a total of five species are new records to State of Rio Grande do Sul (Table I). A list of species recorded in this crop in Brazil is being prepared, including recent data, species diagnosis and identification keys.

As pointed out by Cavalleri \& Kaminski (2007), the lack of inventories on the Brazilian thysanopterofauna is enormous, both in natural and agricultural systems. The present study is the first systematized thrips survey conducted in rice in Brazil, being remarkable in the amount of new records and data obtained. Considering the importance of rice crops in the country, these surveys are the first step to recognize this fauna and its interactions, facilitating studies on the spatial distribution of prejudicial thrips and their monitoring.

Acknowledgements. The authors are grateful to IRGA for access to EEA and to Helena Romanowski for providing laboratory support. To CNPq for financial support to this project. This is the contribution number 550 of the Departamento de Zoologia of UFRGS, Rio Grande do Sul, Brazil.

\section{REFERENCES}

Arakaki, N.; T. Miyoshi \& H. Noda. 2001. Wolbachia-mediated parthenogenesis in the predatory thrips Franklinothrips vespiformis (Thysanoptera: Insecta). Proceedings of the Royal Society of London Ser. B 268: 1011-1016.

Cavalleri, A.; H. P. Romanowski \& L. R. Redaelli. 2006. Thrips species (Insecta: Thysanoptera) inhabiting plants of the Parque Estadual de Itapuã, Viamão, Rio Grande do Sul State, Brazil. Revista Brasileira de Zoologia 23: 367-364.
Cavalleri, A. \& L. A. Kaminski. 2007. A new Holopothrips species damaging Mollinedia (Monimiaceae) leaves in Southern Brazil. Zootaxa 1625: 61-68.

Chander, S. 1999. Thrips infestation in relation to panicle stage in rice. International Rice Research Notes 24: 25-26.

Costa, E. L. N. 2007. Ocorrência de artrópodes e seletividade de inseticidas na cultura do arroz irrigado. Tese de Doutorado, Porto Alegre. Universidade Federal do Rio Grande do Sul, xiv +60 p.

Costa Lima, A. M. 1936. Terceiro catálogo dos insetos que vivem nas plantas do Brasil. Rio de Janeiro. Ministério da Agricultura, $460 \mathrm{p}$.

Embrapa Arroz e Feijão. 2008. Socioeconomia - Participação (\%) dos principais Estados produtores de Arroz (Brasil - 2007). Available at:http://www.cnpaf.embrapa.br/apps/socioeconomia/docs/arroz/ produtores_arroz.htm [01 December 2008].

Ferreira, E. \& P. M. Fernandes. 1985. Tripes em arroz de sequeiro: informações preliminares. Pesquisa Agropecuária Brasileira 20: 505-508.

Grist, D. H. \& R. J. A. W. Lever. 1969. Pests of rice. London, Longmans, $\mathrm{xii}+520 \mathrm{p}$.

Hammer, Ø., D. A. T. Harper \& P. D. Ryan. 2001. PAST: Paleontological statistics software package for education and data analysis. Palaeontologia Electronica 4: 1-9.

IRGA. 2001. Instituto Rio Grandense do Arroz. Arroz irrigado: recomendações técnicas da pesquisa para o sul do Brasil. Porto Alegre, IRGA, $128 \mathrm{p}$.

Kumm, S. \& G. Moritz. 2008. First detection of Wolbachia in arrhenotokous populations of thrips species (Thysanoptera: Thripidae and Phlaeothripidae) and its role in reproduction. Environmental Entomology 37: 1422-1428.

Lewis, T. 1973. Thrips, their biology, ecology and economic importance. London, Academic Press, $349 \mathrm{p}$.

Marullo, R. 1997. The relationship between saprophagy and phytophagy in thrips. Bolletino del Laboratorio di Entomologia Agraria Filippo Silvestri 53: 19-24.

Monteiro, R. C.; L. A. Mound \& R. A. Zucchi. 1999. Thrips (Thysanoptera) as pests of plant production in Brazil. Revista Brasileira de Entomologia 43: $163-171$.

Mound, L. A. 2002. Thysanoptera biodiversity in the Neotropics. Revista de Biologia Tropical 50: 477-484.

Mound, L. A. 2007. Thysanoptera (Thrips) of the World - a checklist. Available at: http://www.ento.csiro.au/thysanoptera/worldthrips.html [01 November 2008].

Mound, L. A. \& G. Kibby. 1998. Thysanoptera - An identification guide. Wallingford, CAB International, $70 \mathrm{p}$.

Mound L. A. \& J. M. Palmer. 1972. Grass-flower infesting thrips of the genus Chirothrips Haliday in Australia. Journal of the Australian Entomological Society 11: 332-339.

Mound, L. A. \& R. Marullo. 1996. The thrips of Central and South America: an introduction (Insecta: Thysanoptera). Memoirs on Entomology, International 6: 1-488.

Pinent, S. M. J.; H. P. Romanowski; L. R. Redaelli \& A. Cavalleri. 2006. Species composition and structure of Thysanoptera communities in different microhabitats at the Parque Estadual de Itapuã, Viamão, RS. Brazilian Journal of Biology 65: 765-779.

Reves, C. P \& G. S. Rillon. 1994. Survey of the thrips fauna and their predators on irrigated, transplanted rice. Philippine Entomologist 9 $268-285$.

Rossetto, C. J.; S. Silveira Neto; D. Link; J. G. Vieira; E. Amante; D. M. De Souza; N. V. Banzatto; A. M. Oliveira. 1972. Pragas do arroz no Brasil. Contribuições técnicas da delegação brasileira à $2^{\mathrm{a}}$ Reunião do Comitê de Arroz para as Américas. Pelotas, FAO, 238 p.

Silva, A. G. A.; C. R. Gonçalves; D. M. Galvão; A. J. L. Gonçalves; J. Gomes; M. M. Silva \& L. Simoni. 1968. Quarto catálogo dos insetos que vivem nas plantas do Brasil, seus parasitos e predadores. Parte II - $1^{\circ}$ Tomo - Insetos, hospedeiros e inimigos naturais. Guanabara, Ministério da Agricultura, Departamento de Defesa e Inspeção Agropecuária, 622 p. 